\title{
PENDAMPINGAN MANAJEMEN USAHA KELOMPOK USAHA BERSAMA (KUB) KOPI ARABIKA DI KABUPATEN TEMANGGUNG
}

\author{
Itsna Iftayani*1, Cahyana Nursidiq ${ }^{2}$, Novita Tri Afifah ${ }^{3}$ \\ ${ }^{1,3}$ Psikologi, Fakultas Ilmu Sosial \\ ${ }^{2}$ Pendidikan Ekonomi, Fakultas Keguruan dan Ilmu Pendidikan \\ Universitas Muhammadiyah Purworejo \\ email: itsnaiftayani@umpwr.ac.id
}

\begin{abstract}
Temanggung Regency is one of the largest coffee-producing districts in Central Java. This motivates coffee farmers to expand their business to the production of ground coffee. One business group that focuses on the coffee business is KUB Tegal Makmur Abadi. The problems that exist in KUB are organizational management, low motivation, and marketing which is still limited to the local sector. Based on these problems, several methods used to solve these problems are (1) Focus Group Discussion, (2) Reorganization, (3) Entrepreneurial Motivation, (4) Training, and (5) MonitoringEvaluation. The results obtained in this mentoring program are KUB Tegal Makmur Abadi feeling (1) The benefits of entrepreneurship assistance programs on business management capabilities, there is already a clear organizational structure formulation and specific assignment of tasks, (2) improvement of marketing skills for KUB members, this can be seen from the ability to create advertisements, manage social media and websites (3) Marketing of Jumprit coffee products that were still in the area of Temanggung Regency has penetrated outside the Island.
\end{abstract}

Keywords: Plastic Waste, Alternative fuel

\begin{abstract}
Abstrak
Kabupaten Temanggung merupakan salah satu kabupaten pengasil kopi terbesar di Jawa Tengah. Hal ini memotivasi petani kopi untuk mengembangkan usaha hingga ke produksi bubuk kopi. Salah satu kelompok usaha yang fokus pada usaha kopi adalah KUB Tegal Makmur Abadi. Permasalahan yang ada pada KUB adalah manajemen organisasi, motivasi yang rendah dan juga pemasaran yang masih terbatas pada sektor lokal. Berdasarkan permasalahan tersebut, beberapa metode yang digunakan untuk menyelesaikan permasalahan tersebut adalah (1) Focus Group Discussion, (2)Reorganisasi, (3) Motivasi Wirausaha, (4) Pelatihan-pelatihan dan (5) Monitoring-Evaluasi. Hasil yang didapatkan dalam program pendampingan ini adalah KUB Tegal Makmur Abadi merasakan (1) Manfaat program pendampingan kewirausahaan terhadap kemampuan manajemen usaha, sudah ada formulasi struktur organisasi yang jelas dan pembagian tugas secara spesifik, (2) peningkatan keterampilan pemasaran bagi anggota KUB, hal ini dapat dilihat dari kemampuan membuat iklan, mengelola media sosial dan website (3) Pemasaran produk jumprit coffee yang tadinya masih diwilayah Kabupaten Temanggung sudah merambah luar pulau.
\end{abstract}

Keywords: Community Partnership, Arabica coffee, Temanggung

\section{PENDAHULUAN}

Kabupaten Temanggung merupakan salah satu kabupaten penghasil kopi terbesar di Jawa Tengah. Pada tahun 2015 Temanggung mampu memghasilkan 1.305, 96 ton kopi Arabika dan 10. 254, 33 ton kopi robusta (BPS, 2015). Melimpahnya biji kopi di kabupaten
Temanggung, menjadikan banyak masyarakat Temanggung tidak hanya menjual biji kopi namun mengolahnya menjadi roastbeen dan bubuk kopi.

Kesadaran petani kopi di kabupaten Temanggung untuk mengembangkan usaha kopi ini cukup memberikan hasil yang optimal. Hal ini dibuktikan dengan 
mampunya kopi Temanggung menembus pasar International, diantaranya ke Australia dan beberapa Negara lain di Eropa. (Harini, 2017). Majunya usaha kopi di Temanggung ini juga didukung oleh beberapa kebijakan Pemerintah Kabupaten yang cukup membantu kemajuan komoditas udaha kopi. Salah satunya adalah Pemerintah menjadikan kopi sebagai produk unggulan kabupaten Temanggung. (Lutfiati dkk, 2018). Selain itu bupati Temanggung juga menerbitkan edaran ke kantor-kantor Pemerintah di Wilayah kabupaten Temanggung untuk menjadikan hari Jum'at sebagai hari minum kopi di Temanggung (Kompas, 2018).

Dukungan yang besar dari pemerintah dan juga iklim masyarakat yang semakin sadar akan pengembangan usaha kopi membuat UMKM dan Kelompok Usaha Bersama (KUB) berlomba-lomba mengembangkan usahanya. Salah satu kelompok usaha yang memproduksi kopi di kabupaten Temanggung adalah KUB Tegal Makmur Abadi. KUB ini terletak di dusun Jumprit, desa Tegalrejo, kecamatan Ngadirejo.

Kopi yang diproduksi oleh KUB ini merupakan kopi Arabica dimana kopi ini merupakan kopi unggulan. Kopi Arabica secara statistik produksinya jauh lebih sedikit dibanding kopi robusta karena kopi Arabica hanya dapat ditanam di dataran tinggi, semakin tinggi tempat menanamnya maka semakin baik pula hasil yang didapatkan. Areal pertanian jumprit sendiri terletak di dataran tinggi yaitu sekitar 1300 diatas permukaan laut (DPL). Nama Jumprit Coffee diambil dari nama dusun di desa Tegalrejo yaitu dusun Jumprit dimana disitu terdapat tempat Wisata Jumprit yang terdiri dari WAPIT (Wisata Alam Jumprit) dan Tempat Pengambilan Air Suci Agama Budha bernama Sendhang Jumprit.

KUB Tegal Makmur abadi merupakan salah satu kelompok usaha bentukan dari kelompok tani Tegal Makmur Abadi. KUB ini beranggotakan
10 orang yang terdiri dari beberapa petani dan warga sekitar dusun Jumprit. KUB ini dibentuk karena potensi hasil biji kopi di areal perkebunan sekitar dusun Jumprit cukup besar dan petani menyadari bahwa ketika dijual dalam bentuk roastbeen dan bubuk akan mendapat nilai jual yang lebih tinggi.

Perkembangan KUB tegal makmur abadi belum cukup signifikan. Berdasarkan Focus Group Discussion (FGD) dengan beberapa pengurus KUB, ada beberapa masalah yang dihadapi oleh KUB yaitu sebagai berikut: (1) Struktur organisasi KUB belum berfungsi sebagaimana mestinya, anggota juga belum tau tugas-tugasnya, (2) Motivasi wirausaha anggota KUB masih rendah, anggota masih menjadikan usaha kopi ini sebagai usaha sampingan, sehingga beberapa anggota fokus sebagai buruh atau petani tembakau, (3) meskipun menggunakan merk yang sama, namun proses pengolahan hingga penjualan dilakukan secara individual oleh masingmasing produsen sehingga tidak ada keuntungan bersama yang didapat oleh anggota KUB, (4) pemasaran masih sebatas konsinyasi di toko-toko sekitar Temanggung dan FB pribadi.

Berdasarkan permasalahan tersebut maka perlu dilakukan pendampingan manajemen usaha agar KUB Tegal Makmur Abadi dapat berkembang dan menjadi KUB yang lebih produktif.

\section{METODE PENGABDIAN}

Berdasarkan beberapa permasalahan pada KUB Tegal Makmur Abadi maka diperlukan metode pendampingan yang tepat. Metode yang digunakan dalam program kemitraan masyarakat ini adalah program pendampingan berkelanjutan. Program ini menekankan bahwa program pendampingan yang dilaksanakan tidak hanya selama program berlangsung, akan tetapi berlanjut hingga pasca program jika memang dibutuhkan. 
Program

pendampingan

berkelanjutan yang digunakan dalam program kemitraan masyarakat ini memuat beberapa prinsip dasar yaitu (1) Keberlanjutan, dalam program ini proses pelatihan dan pendampingan tidak hanya berhenti selama program (5 bulan) akan tetapi tim pengusul akan memberikan pendampingan pasca program jika memang dibutuhkan. (2) Kemandirian, dalam pelaksanaan program ini anggota mitra dimotivasi untuk dapat bergerak secara mandiri dan tidak tergantung pada pihak lain seperti investor. Mitra akan dapat mengembangkan usaha dengan Sumber Daya Manusia yang ada, Modal yang dimiliki dan Keterampilan yang sudah diberikan dan (3) Terintegrasi, program ini membuat beberapa sub kegiatan yang satu dengan yang lain saling terintegrasi sehingga anggota mitra dapat secara penuh mendapatkan manfaat dari kegiatan pelatihan dan pendampingan ini.

Pelaksanaan program pendampingan berlangsung selama kurang lebih 5 bulan, akan tetapi monitoring dan evaluasi akan tetap dilaksanakan setelah program selesai dilaksanakan. Program Kemitraan ini dipusatkan di lokasi KUB Tegal Makmur Abadi yaitu di desa Tegalrejo, Kecamatan Ngadirejo, Kabupaten Temanggung. Kegiatan FGD dilaksanakan di tempat produksi atau kafe sedangkan kegiatan pelatihan dilaksanakan di Wisata Alam Jumprit (Wapit) yang letaknya tidak jauh dari tempat produksi.

Beberapa langkah pendampingan yang dilaksanakan adalah sebagai berikut: (1) Mengadakan FGD dengan pengurus KUB terkait arah pengembangan KUB (visi dan misi KUB), (2) Melakukan reorganisasi KUB sesuai dengan kompetensi masingmasing anggota KUB, (3) menyusun deskripsi kerja masing-masing bidang, (4) memberikan pelatihan motivasi wirausaha kepada seluruh anggota, (5) memberikan pelatihan manajemen usaha, pembukuan dan pemasaran serta (6) melakukan monitoring dan evaluasi program.

\section{HASIL DAN PEMBAHASAN}

Program pendampingan berlangsung mulai bulan Maret hingga Juli 2019. Secara umum semua kegiatan yang sudah direncanakan telah terlaksana dengan baik. Kegiatan pendampingan dimulai dengan diskusi (FGD) dengan pengurus inti KUB terkait arah pengembangan KUB. Pada diskusi ini menghasilkan analisis masalahmasalah pada KUB, formulasi solusi yang tepat untuk masing-masing masalah dan arah pengembangan KUB ke depan. Setelah didapatkan hasil yang cukup memadai maka disusunlah Visi, Misi dan juga profil KUB secara umum.

Kegiatan yang kedua adalah reorganisasi KUB. Hasil yang didapatkan dari kegiatan ini adalah struktur organisasi KUB yang baru disesuaikan dengan kemampuan masing-masing anggota. Formulasi struktur organisasi ini didapatkan dari rapat pengurus ini KUB, identifikasi bakat dan kemampuan masingmasing anggota KUB. Hal ini berbeda dengan struktur organisasi sebelumnya yang masih belum disesuaikan dengan kemampuan masing-masing.

Langkah yang dilakukan menyusun struktur organisasi yang baru adalah mensosialisasikan deskripsi kerja masingmasing bagian yang sudah disusun sebelumnya. Penyusunan deskripsi kerja dilakukan setelah menganalisis pola organisasi yang dibutuhkan oleh KUB. Penyusunan deskripsi kerja diawali dengan FGD dengan pengurus inti KUB dan kemudian dilakukan analisis jabatan sederhana dan disusunlah pembagian kerja masing-masing bagian. Setelah selesai disusun maka deskripsi kerja disosialisasikan kepada seluruh anggota KUB 


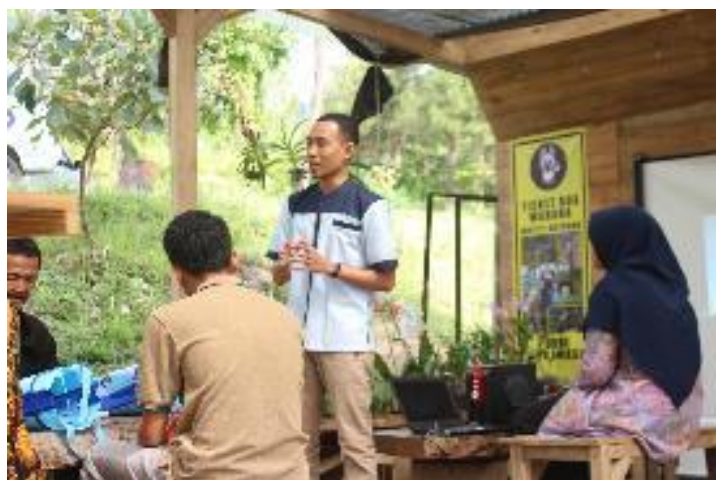

Gambar 1. Kegiatan focus group discussion (FGD) Anggota KUB Tegal Makmur Abadi

Setelah tersusun struktur organisasi yang terarah dan sesuai kemampuan masing-masing maka anggota KUB diberikan beberapa pelatihan. Ada tiga pelatihan utama yang diberikan kepada anggota KUB yaitu (1) Pelatihan manajemen usaha, pelatihan ini diberikan kepada seluruh anggota KUB. Materi yang disampaikan dalam pelatihan ini adalah motivasi wirausaha, pengetahuan dasar mengenai wirausaha, bagaimana mengelola sebuah usaha dan beberapa materi terkait organisasi. (2) Pelatihan pembukuan yang meliputi materi administrasi keuangan, buku kas, laporan laba/rugi dan diakhiri dengan praktek membuat laporan keuangan sederhana. (3) Pelatihan pemasaran online dan pengelolaan website. Pelatihan ini dimulai dengan memberikan gambaran pentingnya pemasaran dalam sebuah usaha, beberapa tips pemasaran secara umum dan diberikan materi pemasaran online yaitu bagaimana mengelola akun media sosial, akun market place dan juga website.

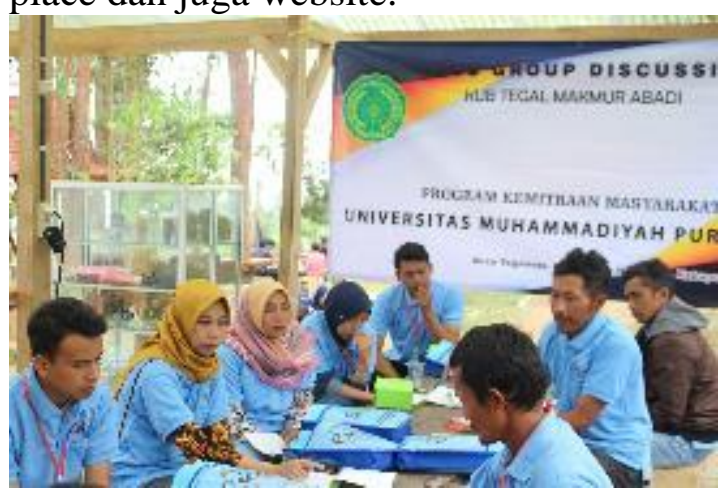

Gambar 2. Kegiatan Pelatihan Manajemen Usaha
Melalui beberapa pelatihan yang diberikan kepada anggota KUB Tegal Makmur Abadi ini diharapkan KUB dapat lebih mandiri dalam mengelola usahanya. KUB tidak perlu bergantung kepada investor karena KUB sudah mampu menganalisis kebutuhan-kebutuhanya sendiri.

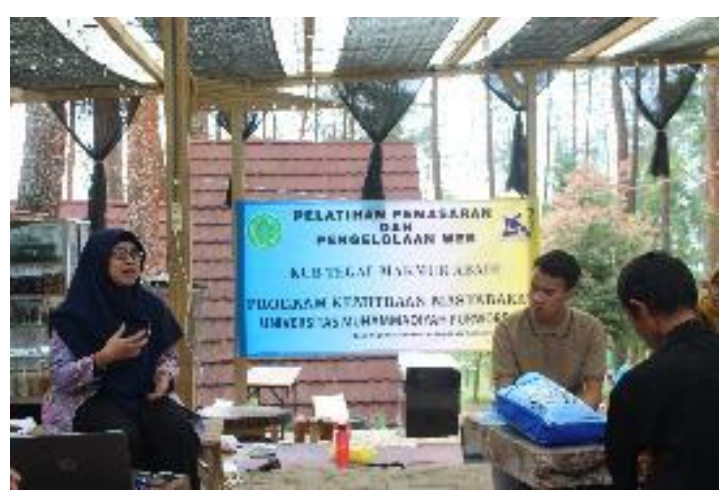

Gambar 3. Pelatihan Pemasaran dan Pengelolaan website

Setelah dilaksanakan pelatihan-pelatihan, maka pengusul melakukan monitoring dan evaluasi terhadap program kegiatan. Program monitoring dilaksanakan pada beberapa aspek yaitu terkait manajemen usaha, produksi, pembukuan dan pemasaran. Setelah diberikan pelatihan-pelatihan tersebut anggota KUB diminta untuk mengerjakan tugas masingmasing. Pengusul memonitor setiap 2 minggu sekali, diantaranya adalah melalui laporan sederhana perkembangan atau kemajuan KUB. Laporan disusun secara terulis dan informasi lisan disampaikan ketika tim PKM mengadakan FGD lanjutan.

Setelah program pendampingan dilaksanakan, ada beberapa hasil yang dicapai yaitu sebagai berikut (1) Keterampilan atau kemampuan manajemen usaha, meningkatnya keterampilan manajemen dapat dilihat dari pemahaman anggota KUB terhadap struktur organisasi yang ada. Terdapat formulasi struktur organisasi yang jelas dan pembagian tugas secara spesifik, (2) Peningkatan keterampilan pemasaran bagi anggota KUB, hal ini dapat dilihat dari kemampuan membuat iklan, mengelola media sosial dan website. Berdasarkan hasil pelatihan, dapat diketahui bahwa sebagian besar anggota KUB mampu memahami dan membuat iklan sederhana. (3) Semakin meluasnya pasar produk jumprit coffee. Hal ini dapat dilihat dari pemesanan 
produk yang tidak hanya terbatas di wilayah kabupaten Temanggung namun juga merambah ke berbagai kota yang lain seperti Bandung, Purworejo, Magelang, Banyuwangi dan Lampung.

Selain beberapa hal diatas, untuk mendukung program juga dibuatkan website jumpritcoffee.com, akun media sosial instagram, akun shoopee dan juga video profil jumprit coffee untuk mengenalkan produk dari KUB Tegal Makmur Abadi ke pasar nasional .

\section{SIMPULAN}

Program Kemitraan Masyarakat ini telah berhasil dilaksanakan, pendampingan dilakukan selama kurang lebih lima bulan. Hasil dari program ini secara umum adalah kemampuan manajemen dari anggota KUB meningkat, ketrampilan pemasaran semakin baik dan juga pemasaran produk semakin meluas. Karena program yang dilaksanakan merupakan program berkelanjutan, maka anggota KUB Tegal Makmur Abadi dapat terus melakukan konsultasi kepada tim.

\section{UCAPAN TERIMAKASIH}

Terima kasih kepada kemenristekdikti yang telah memberikan dana dalam program kemitraan masyarakat ini.

\section{DAFTAR PUSTAKA}

[1]. Badan Pusat Statistik. 2015. Jawa Tengah dalam Angka 2015. Semarang: BPS Provinsi Jawa Tengah

[2]. Harini. 2017. Temanggung Jajaki Eskpor Kopi ke Australia. https://www.validnews.id/Temanggun g-Jajaki-Ekspor-Kopi-Ke-Australia-V0000554. 08 Juli 2019. (21.18).

[3]. Fitriana, Ika. 2018. Bupati Temanggung Canangkan Gerakan "Sehari Minum Kopi” Setiap Jum'at. https://regional.kompas.com/read/20 18/10/12/15214101/bupatitemanggung-canangkan-gerakansehari-minum-kopi-setiap-jumat.

Juli 2019. (15.51).

[4]. Lutfiati, Heni; Praja, Chrisna Bagus Edhita \& Setiyo, Muji.
Pengembangan Produk Unggulan Daerah Kopi Robusta Temanggung. Prosiding Seminar Nasional Pengabdian Masyarakat (SENADIMAS) Unisri. https://ejurnal.unisri.ac.id/index.php/ sndms/article/view/2410. 20 Juli 2019. (22.20).

[5]. Pratiwi, Retno Rahmawati. 2016. Hambatan dan Strategi Pengembangan Usaha Kopi dalam Upaya Peningkatan Produksi di Kecamatan Candiroto Kabupaten Temanggung. Skripsi. Semarang: Universitas Negeri Semarang 